\title{
Pelatihan Peningkatan Kualitas Produk dan Pemasaran Usaha Bubuk Biji Salak di Desa Sungai Langka Kabupaten Pesawaran
}

\author{
Kiagus Andi*, Fitra Dharma, Rindu Rika Gamayuni
}

Akuntansi, Universitas Lampung, Bandar Lampung, 35145, Lampung, Indonesia

\begin{abstract}
Abstrak.
Kegiatan Pengabdian Kepada Masyarakat ini ditujukan pada warga desa penggerak usaha bubuk biji salak, yaitu Kelompok Wanita Tani (KWT) Dusun 5, Desa Sungai Langka, Kecamatan Gedong Tataan, Kabupaten Pesawaran, Lampung. Desa Sungai Langka adalah desa penghasil tanaman salak, berada di daerah dataran tinggi yang sejuk. Usaha produksi dan penjualan bubuk biji salak ini sudah dilakukan oleh KWT, namun masih menemui banyak kendala dalam proses produksi dan pemasarannya. Produk minuman dari bubuk biji salak memiliki rasa yang enak dan kandungan manfaat yang banyak untuk kesehatan. Namun permasalahannya adalah, masih terbatasnya kualitas produk dan jumlah produksi bubuk biji salak yang dihasilkan dan masih minimnya penjualan serta pemasaran. Target yang ingin dicapai adalah peningkatan kualitas produk, peningkatan penjualan dan pemasaran bubuk biji salak. Solusi dan metode untuk menyelesaikan permasalahan tersebut antaralain dengan memberikan pelatihan bagaimana cara untuk meningkatkan kualitas produk, produksi dan penjualan serta pemasaran bubuk biji salak, sehingga terjadi peningkatan perekonomian warga desa. Untuk meningkatkan pemasarannya, pihak pengabdi dari FEB Unila telah membuatkan disain label produk yang baru yang lebih menarik tampilannya agar produk lebih banyak terjual, selain itu juga membelikan mesin shiller yang lebih baik untuk meningkatkan kualitas kemasan produk.
\end{abstract}

Kata kunci.

kualitas produk, pemasaran, bubuk biji salak.

\section{PENDAHULUAN}

Kegiatan pengabdian kepada masyarakat ini dilakukan berdsarkan permasalahan yang ditemui masyarakat. Desa Sungai Langka adalah salah satu desa penghasil buah salak. Hal ini menimbulkan inisiatif sekelompok warga desa untuk mengolah limbah salak lebih lanjut menjadi produk yang lebih menguntungkan, yaitu dengan mengolah biji salak menjadi bubuk biji salak. Bubuk biji salak merupakan bubuk yang terbuat dari biji buah salak. Bubuk ini memang belum sepopuler bubuk-bubuk pada umumnya. Tidak hanya memiliki cita rasa yang khas bubuk ini juga memiliki banyak manfaat bagi kesehatan karena terdapat

* Corresponding author: kiagus_andi@yahoo.co.id

Received 16 November 2020; Received in revised form 27 November 2020; Accepted 7 December 2020

Available online 24 December 2020

Lembaga Penelitian dan Pengabdian Kepada Masyarakat

Universitas Lampung 
beberapa kandungan. Kandungan yang terdapat di dalam nya meliputi kandungan protein, mineral, lemak, selulosa, pati, karbohidrat dan masih banyak lagi. Kandungan tersebut dipercaya memiliki banyak manfaat dan khasiat bagi tubuh. Manfaat lainnya adalah memperlancar sistem perncernaan, mengobati diare, menambah tenaga, meningkatkan kecerdasan, dan mencegah hipertensi. Berdasarkan hasil survey, wawancara dan diskusi bersama mitra desa, dapat didentifikasi bahwa tuntutan yang dihadapi desa saat ini adalah: masih terbatasnya pengetahuan tentang cara peningkatan kualitas produk, penjualan dan pemasaran produk. Oleh karena itu kegiatan pengabdian kepada masyarakat ini dilakukan dengan memberikan pelatihan kepada warga mengenai cara peningkatan kualitas produk, penjualan dan pemasaran produk bubuk biji salak. Bubuk biji salak memiliki potensi yang sangat baik untuk dikembangkan di desa ini, karena bahan bakunya yang mudah diperoleh di sekitar warga, dan dapat menjadi produk ikonik Desa Sungai Langka. Apabila dikelola dengan baik maka produk ini dapat menjadi salah satu sumber untuk menambah pendapatan keluarga dan meningkatkan perekonomian warga desa. Peraturan Menteri Dalam Negeri Nomor 113 Tahun 2014 tentang Pengelolaan Keuangan Desa, menyatakan perlunya pengelolaan keuangan desa yang baik dalam rangka meningkatkan perekonomian dan kemakmuran warga desa [1], sejalan pula dengan Undang-Undang Republik Indonesia Nomor 6 Tahun 2014 tentang Desa [2].

Berdasarkan hasil survey, wawancara, dan diskusi dengan warga desa pengusaha bubuk biji salak, permasalahan yang terjadi saat ini adalah: Kesulitan dalam meningkatkan kualitas produk dan pemasaran, karena kurangnya tenaga dan peralatan yang memadai, terbatasnya pengetahuan. Tujuan kegiatan pengabdian kepada masyarakat ini adalah untuk menerapkan dan menyebarluaskan hasil-hasil penelitian/kajian kepada masyarakat sebagai bagian dari upaya untuk memberdayakan dan meningkatkan kesejahteraan masyarakat. Manfaat kegiatan ini adalah untuk meningkatkan kualitas produk, produksi, penjualan dan pemasaran produk bubuk biji salak sehingga perekonomian warga meningkat. Berdasarkan Hongren, bahwa dengan pengelolaan biaya produksi yang baik dapat menghasilkan harga jual yang tepat [3].

\section{METODE}

Kegiatan pengabdian kepada masyarakat di Desa Sungai Langka ini dilakukan dengan metode dan tahapan sebagai berikut:

a. Analisis situasi, untuk mengetahui permasalahan yang terjadi dan kebutuhan warga desa pengusaha bubuk biji salak.

b. Mengadakan pre-test, utnuk mengetahui pengetahuan awal peserta

c. Memberikan pelatihan tentang cara peningkatan kualitas produk, jumlah produksi dengan memberikan pengetahuan cara peningkatan kualitas produk dari segi kualitas bahan baku, bahan penolong, cara pemrosesan yang baik untuk menjaga mutu produk (rasa, kandungan gizi yang terjaga, kebersihan, keawetan produk).

d. Memberi pengetahuan tentang biaya dan cara perhitungan harga jual yang tepat, agar tercapai peningkatan penjualan. Pengeloaan biaya produksi yang tepat akan menghasilkan harga jual yang tepat [4].

e. Memberikan pengetahuan tentang cara memperluas pangsa pasar dengan membuatkan website untuk penjualan online, penjualan melalui media sosial, lazada, shopee, dan penjualan ke berbagai minimarket.

f. Post-test di akhir pelatihan untuk mengtahui kemampuan akhir peserta.

g. Pemantauan dan evaluasi kegiatan

Selanjutnyan akan dilakukan evaluasi apakah warga desa pengusaha bubuk biji salak telah berhasil meningkatkan kualitas produk, jumlah produksi dan penjualan serta pemasaran bubuk biji salak. 
Berikut adalah kegiatan yang akan didiseminasi ke masyarakat dan prosedur kerja untuk mendukung realisasi metode yang ditawarkan.

Table 1. Deskripsi kegiatan.

\begin{tabular}{cll}
\hline No. & \multicolumn{1}{c}{ Kegiatan } & \multicolumn{1}{c}{ Prosedur Kerja } \\
\hline 1 & $\begin{array}{l}\text { Memberi pelatihan cara } \\
\text { peningkatan kualitas produk }\end{array}$ & $\begin{array}{l}\text { Pemaparan pengetahuan dengan cara presentasi dengan } \\
\text { menggunakan slide projector, memberikan video yang } \\
\text { menginspirasi mengenai cara peningkatan kualitas produk } \\
\text { dan jumlah produksi. }\end{array}$ \\
2 & $\begin{array}{l}\text { Memberi pelatihan tentang cara } \\
\text { meningkatkan penjuala } \\
\text { menentukan harga jual yang tepat }\end{array}$ & $\begin{array}{l}\text { Pemaparan pengetahuan dengan cara presentasi dengan } \\
\text { menggunakan slide projector, memberikan video yang } \\
\text { menginspirasi }\end{array}$ \\
$3 \quad \begin{array}{l}\text { Memberi pelatihan tentang cara } \\
\text { membuat website untuk penjualan } \\
\text { online, mengenalkan cara } \\
\text { menggunakan media sosial untuk } \\
\text { memperluas pangsa pasar. }\end{array}$ & $\begin{array}{l}\text { Tutorial cara membuat website penjualan online, penjualan } \\
\text { melalui media social, memberi pengetahuan cara } \\
\text { memperluas pangsa pasar. }\end{array}$ \\
\hline
\end{tabular}

Evaluasi dilakukan setelah diadakan pelatihan. Evaluasi dengan memberikan beberapa pertanyaan untuk dijawab peserta pelatihan, untuk mengetahui sejauhmana peningkatan pemahaman dan pengetahuan peserta terhadap pelatihan yang sudah diberikan. Keberlanjutan program, dilakukan dengan melakukan evaluasi dari satu sampai dengan beberapa bulan setelah berlangsungnya kegiatan pengabdian.

Tabel 2. Evaluasi dan keberlanjutan program.

\begin{tabular}{cll}
\hline No & \multicolumn{1}{c}{ Tahap evaluasi } & \multicolumn{1}{c}{ Kegiatan } \\
\hline 1 & $\begin{array}{l}\text { Evaluasi pre-test (sebelum kegiatan } \\
\text { pelatihan) dan post-test (setelah } \\
\text { kegiatan pelatihan). }\end{array}$ & $\begin{array}{l}\text { Peserta diberikan beberapa pertanyaan tertulis dan } \\
\text { diminta untuk menjawabnya utnuk mengetahui } \\
\text { sejauhmana pengetahuan dan pemahaman peserta } \\
\text { terhadap pelatihan yang telah diberikan. }\end{array}$ \\
$2 \quad \begin{array}{l}\text { Evaluasi 1 bulan setelah kegiatan } \\
\text { pelatihan }\end{array}$ & $\begin{array}{l}\text { Evaluasi untuk mengetahui seberapa besar peningkatan } \\
\text { kualitas produk dan jumlah produksi yang telah dicapai, } \\
\text { peningkatan keuntungan yang diperoleh pada 1 bulan } \\
\text { setelah kegiatan, dan permasalahan yang dihadapi yang } \\
\text { menghambat tercapainya tujuan. }\end{array}$ \\
& $\begin{array}{l}\text { Evaluasi 2 bulan sampai 3 bulan } \\
\text { setelah kegiatan pelatihan }\end{array}$ & $\begin{array}{l}\text { Evaluantuk mengetahui seberapa besar peningkatan } \\
\text { penjualan yang telah dicapai, pada } 2 \text { bulan setelah } \\
\text { kegiatan, dan permasalahan yang dihadapi yang } \\
\text { menghambat tercapainya tujuan. }\end{array}$ \\
\hline
\end{tabular}

\section{HASIL DAN PEMBAHASAN}

Kegiatan pengabdian kepada masyarakat ini dilaksanakan pada hari Sabtu, 22 Agustus 2020, bertempat di Desa Sungai Langka, Kabupaten Pesawaran. Peserta adalah ibu-ibu anggota Kelompok Wanita Tani dan ibu rumah tangga lainnya, ketua pelaksana dan anggota pelaksana pengabdian kepada masyarakat dari UNILA, dibantu beberapa mahasiswa S2 MSI FEB UNILA, bertempat di aula Desa Sungai Langka.

Tahapan kegiatan sebagai berikut:

1. Pembukaan oleh Ketua Pengabdian dan Ketua Kelompok Wanita Tani.

2. Pre-test, peserta diminta menjawab pertanyaan utnuk mengetahui kondisi saat ini dan mengetahui sejauhmana pemahaman peserta dalam hal peningkatn kualitas produk.

3. Memberi pelatihan cara peningkatan kualitas produk dan jumlah produksi

4. Memberi pelatihan tentang cara membuat website untuk penjualan online, mengenalkan cara menggunakan media sosial untuk memperluas pangsa pasar.

5. Memberi pelatihan cara perhitungan harga jual yang tepat dan efisiensi biaya produksi, serta peningkatan penjualan 
6. Memberi pelatihan tentang cara manajemen pengelolaan keuangan, produksi dan pemasaran produk

7. Praktek penggunaan shiller (alat perekat kemasan)

8. Perancangan desain label produk yang baru

9. Evaluasi hasil (post-test)

Berdasarkan hasil post-test, terdapat peningkatan pengetahuan ibu-ibu kelompok wanita tani tentang cara pengingkatan produksi dan penjualan produk.

10. Percobaan penggunaan alat pengemas yang baru

11. Pembuatan desain label kemasan yang lebih menarik dan informative disbanding desain sebelumnya.

12. Evaluasi pada 1 bulan setelah pelaksanaan kegiatan

1 bulan setelah berlangsungnya kegiatan, ibu-ibu kelompok wanita tani merasakan manfaat baik dari ilmu yang diperoleh maupun dengan penggunaan alat produksi yang baru, sebagai berikut: dengan adanya alat pengemas yang baru sangat membantu mempermudah pekerjaan dan kualitas kemasan lebih baik (tidak mudah bocor). Alat shiller yang lama, kemasan produk sering bocor dan kemasan mudah rusak sehingga harus diganti yang mengakibatkan pemborosan biaya kemasan. Selain itu juga telah dibuatkan desain label produk yang baru yang lebih menarik konsumen dan lebih informative (memberikan info lengkap terkait manfaat dan cara penyajian minuman bubuk biji salak). Label produk yang baru telah dicetak dan digunakan. Beberapa konsumen yang telah mencoba produk minuman biji salak ini merasakan manfaat setelah mengkonsumsi produk ini dan melakukan repeat order (pembelian ulang).

\section{KESIMPULAN DAN SARAN}

Kegiatan pengabdian kepada masyarakat bagi ibu-ibu kelompok wanita tani di Desa Pesawaran dilaksanakan dengan memberi pelatihan dan memberikan bantuan alat kemasan dan disain label produk yang baru yang lebih menarik dan informatif, agar konsumen lebih tertarik sehingga diharapkan penjualan meningkat. Sebagai saran, dibutuhkan adanya pendampingan berkelanjutan dalam peningkatan kualitas produksi dan kontinuitas pemasaran produk.

\section{DAFTAR PUSTAKA}

[1] Peraturan Menteri Dalam Negeri Nomor 113 Tahun 2014 tentang Pengelolaan Keuangan Desa.

[2] Undang-Undang Republik Indonesia Nomor 6 Tahun 2014 tentang Desa.

[3] Hongren, Charles., Srikant Datar, George Foster. 2008. Akuntansi Biaya: Dengan Penekanan Manajerial. Erlangga. Jakarta. Edisi 12.

[4] Rainborn, Cecily A., Michael R. Kinney. 2011. Akuntansi Biaya: Dasar dan Perkembangannya. Penerbit Salemba Empat. Jakarta. 